\title{
Housing Sustainability Challenges in a Nigerian City
}

\author{
Adewale Oluseyi Adunola \\ Postdoctoral Research Fellow \\ Department of Architecture, University of Johannesburg, South Africa \\ Tel : 27-623-403-707 E-mail: adewalea@uj.ac.za
}

Received: August 2, 2015 Accepted: August 21, 2015

doi:10.5296/emsd.v4i2.8092 URL: http://dx.doi.org/10.5296/emsd.v4i2.8092

\begin{abstract}
This paper discusses housing sustainability challenges and applicable sustainable urban renewal strategy for Nigerian cities, and thereby emphasizes the dimension of government-instituted urban renewal policy. This is with a view to projecting the need for urban housing sustainability with respect to developing countries A field survey conducted in Ile-Ife, a typical Nigerian city in its South-Western region is used to appraise the extent of the housing sustainability challenges. The four areas for the survey- Itakogun-Okerewe, Ogbingbin, Obalufon-Ilara and Igboya, were purposively selected from the Ife Central Local Government which constitutes the central area of Ile-Ife. The conditions of the houses and neighbourhoods were assessed by means of administration of questionnaire to residents and observation. In each of the four areas surveyed, the findings indicated that the built environment was deplorable. The indoor and outdoor environmental quality factors were unsatisfactory to respondents and the essential services were not in serviceable condition. The study concluded that the poor and uncomfortable housing and environmental living conditions in the city core areas reflected the stress of urbanization. The findings, though limited in scope to one typical Nigerian city, give insight that housing challenges of urban central areas are in unsustainable dimensions. It was recommended that there must be a commitment to adequate and far-reaching urban renewal programmes based on sustainability, energy conservation and human comfort. Government intervention in the dynamics of the urban environment in Nigeria is urgently required to effect good governance and acceptable urban management.
\end{abstract}

Keywords: Energy conservation, Governance, Urban renewal, Urbanization, Sustainability

\section{Introduction}

A key challenge in urban governance is the combined management of the urban buildings and infrastructure in relation to the residents and the urban anthropogenic activities in relation to 
the environment. The city environment can be considered to be full of energy consuming, waste producing and heat generating activities. This is mainly due to the high population concentration, industrialization processes, vehicular traffic congestion and construction operations. According to Mabogunje (2011), many countries in Africa are moving towards having 40 to 50 per cent of their population living in cities. The high population density in the city creates challenges in the aspects of urban residential accommodation quality and quantity, socio-economic and infrastructural development, environmental quality as well as energy demand. Urbanization is the root cause of the high rates of environmental degradation, pollution and social delinquency (Mabogunje 2002). Added to this is the effect of globalization. According to Mabogunje (2011), the prevailing process of globalization is fueling the rate of urbanization especially in developing countries.

The residential areas, whether of good or bad quality, have indispensable contribution towards the socio-economic development since housing is a basic need for the urban multifaceted workforce. Slums have sprung up in diverse parts of the cities of developing countries without any tangible provisions for appropriateness or sustainability (Ooi and Phua 2007). Much work had been done on the problems of urbanization and housing in cities. However in Nigeria, a proper understanding of the peculiar energy, environmental and infrastructural problems would be required to meaningfully tackle the environmental issue of improving the urban living conditions. There is also a development in the urban issues relating to building sustainability which need to be focused on using a contextual approach. This paper will attempt to identify peculiar problems in the urban central areas in a typical Nigerian city and offer recommendations to improve the living standard of the city dwellers in relation to the sustainability of the built environment. The findings of the study will be used to further substantiate the gravity of the need for drastic governmental measures to improve the living standards in the cities of developing countries.

The paper is presented in sections after this introduction as follows: Section 2 describes the Problems of the Urban Centres while Section 3 provides a discussion about the Study Area; the Data Collection methodology is highlighted in Section 4 while the summary of the key Findings are presented in Section 5; and Section 6 provides a discussion on the Applicable Sustainable Urban Renewal Strategy.

\section{The Problems of Urban Centres}

The problems of urban development are very substantial in all urbanizing communities. Many governments and people all over the world are concerned about the problems of the cities which are already reaching alarming dimensions. One phenomenon that has remarkably influenced cities all over the world is urbanization. The peculiarities of the problems associated with the urban environment relate to the demands of unmonitored extensive urbanization. According to Ojo (1978), urbanization problems can easily gather momentum and reach alarming proportions if unattended to. The problems are both generative and cumulative because presently, according to UNDP (2005), one billion people or one third of the world's population is estimated to be living in either slum or squatter settlements. The rapid urbanization has outpaced the ability of city authorities to provide adequate and 
appropriate housing, environmental and health infrastructure (Ooi and Phua 2007).

The Habitat Agenda adopted by the United Nations in 1996 identified the problems confronting urban centres and their inhabitants in the developing countries as: Inadequate financial resources, lack of employment opportunities, spreading homelessness and expansion of squatter settlements, increased poverty and a widening gap between the rich and the poor, growing insecurity and rising crime rates, inadequate and deteriorating building stock as well as services and infrastructure. Other problems include lack of health and educational facilities, improper land use, insecure land tenure, rising traffic congestion, increasing pollution, lack of green spaces, inadequate water supply and sanitation, uncoordinated urban development and an increasing vulnerability to disaster.

Mabogunje (1978) categorized the failure of Nigerian urban centres under four heads: employment, liveability, manageability and serviceability. The cities in Nigeria have exhibited almost all the listed problems above. These problems have arisen in response to the urbanization processes of the Nigerian development. There is inadequate capacity to manage the urbanization processes in Nigeria with housing in short supply (Olotuah 2005). The rate of urbanization has been too rapid for the infrastructural, socio-economic and technological development of the country in general and the cities in particular. According to Okoko (2001), Mabogunje (2002), the present day Nigerian city is typified by substandard housing and transportation problems, congestion, low productivity, poverty, crime and juvenile delinquency due to rural-urban drift. There is a high rate of environmental degradation, pollution and social delinquency because of uncoordinated urbanization. Ogunshakin (1994) stated that developing countries are faced with seemingly endless problems of economic regression, social stagnation and debt crisis coupled with political instability and externally imposed development options. These negative situations induce and complicate the urban housing crisis, infrastructural over loads and underdevelopment of services.

The problems highlighted are not limited to cities of the developing countries. The major problems facing nearly all the great cities in the world are uncontrolled growth. The population of the whole world is presently heavily concentrated in cities, and throughout the world, in both developed and developing countries, men and women are flocking to cities from rural areas in ever-increasing numbers. As a result, the quality of life for many city dwellers is poor and sometimes declining (Mabogunje 2002, Olotuah 2005). There should be a proper understanding of these catalogues of environmental and infrastructural problems in the cities of developing countries. An appraisal of these challenges need to be done at local levels to enable an analytical and practical input as regards the possible solutions to the challenges. A survey of the existing conditions in Ile-Ife was therefore embarked upon to give additional information concerning the critical areas of the housing and environmental problems.

\section{Study Area}

Ile-Ife is a small city in South-Western Nigeria located on latitude $7.5^{\circ} \mathrm{N}$ and longitude $4.5^{\circ} \mathrm{E}$. It is located in the tropical rain forest vegetation belt and has an elevation of about $275 \mathrm{~m}$ above sea level. The study area falls within the warm-humid climatic zone. In the 
warm-humid zone there is very high solar radiation, high temperatures, high humidity and high rainfall but accompanied by relatively low wind speed (Hyde 2000). The climatic data for Ile-Ife showed that the climatic context combined high temperature $\left(\operatorname{mean}_{\max }-31.4^{\circ} \mathrm{C}\right)$, high humidity $\left(\operatorname{mean}_{\max }-83.3 \%\right)$ and low air velocity $\left(\operatorname{mean}_{\max }-1.55 \mathrm{~m} / \mathrm{s}\right)$ with high precipitation (1691.1mm annual). The maximum temperatures are above $30^{\circ} \mathrm{C}$ for all months with the exception of August and September.

The city is fast-growing with the effects of urbanization like many other cities in Nigeria, especially due to the location of Obafemi Awolowo University in the township since 1962. The city is worthy of all kinds of study because it has a lot of history behind it as an ancient city. It is the acknowledged cradle of the Yoruba race (one of the major ethnic groups in Nigeria) and serves as a typical Nigerian cultural city. Apart from the socio-magnetic impact of the University, Ile-Ife is also a trade centre with a good number of businesses attracting people from the surrounding rural areas. The central areas of Ile-Ife are characterized by ineffective neighbourhood planning and indiscriminate erection of substandard structures for housing with high population concentration. The areas for the survey were purposively selected from the Ife Central Local Government which constitutes the central area of Ile-Ife.

\section{Method of Data Collection}

The exercise was aimed at defining and appraising the extent of the housing and environmental problems in the core areas of the city. A purposive sampling was done to select central areas of Ile-Ife for the survey. The four areas selected were Itakogun/ Okerewe, Ogbingbin, Obalufon/ Ilara and Igboya. In each area selected for the survey with an estimated 200 houses, ten percent ( 20 houses) were systematically selected. The first house was selected randomly and then every tenth house was subsequently chosen as the houses were numbered respectively. The condition of the houses and neighbourhoods were assessed by observation, questionnaire administration and interview of residents. One male and one female adult in each of the selected houses were selected respectively to fill the questionnaire.

Using appropriate rating scales in each case, the indoor environmental quality factors that were assessed by respondents were the following: thermal comfort, ventilation, indoor air quality, and illumination of the houses. Respondents were also asked to assess the outdoor environmental factors like landscape features, sanitation, environmental air quality and drainage. The respondents also assessed essential services and infrastructural provisions in their neighbourhoods such as water supply, electricity supply, roads, telecommunication and sewage disposal. With the above study procedure, data was collected and descriptive statistics of percentages was applied to give the analysis of the results.

\section{Analysis of Findings}

Reported under this section are the findings from the case study as obtained from the questionnaire filled by the respondents and observation done in the areas. The results of the survey for the following central areas in Ile-Ife- Itakogun/ Okerewe street, Ogbingbin street, Obalufon/ Ilara street and Igboya street, are presented in Tables 1,2 and 3. The amenities 


\section{Ml Macrothink}

provided for the areas are quite inadequate as indicated in the survey results in Table 1 . The residents depend on dug-wells majorly for water supply in the four areas surveyed. Ilara, Ogbingbin and Igboya have partial unsustained pipe-borne water supply, while the pipes in Okerewe are not flowing. In all the cases the pipe-borne water supply is reported to be erratic. The proportion of houses with standard water closets are only $20 \%$ in Okerewe, Ogbingbin and Ilara while it is $40 \%$ in Igboya. The use of latrines is predominant in these areas. However, in Ilara some houses (20\%) do not even have this basic amenity.

Electricity supply is also found to be inadequate as reported by respondents. The supply of electricity in Okerewe, Ogbingbin and Ilara is 40-75\% erratic. Only 15\% and 20\% of houses in Ilara and Ogbingbin respectively have electricity connection problems. The dependence on generating sets is found to range from $40-60 \%$ in the four areas. Telecommunication is also found to be noticeably unsatisfactory to the residents with Ilara having the highest dissatisfaction level of 55\%. Refuse disposal is a critical problem in Okerewe, Ogbingbin and Ilara where only $40-75 \%$ of the refuse is disposed of adequately. The remainder constitutes blockage to drainage gutters and indiscriminate refuse dumps. The condition of the roads is assessed to be averagely motorable with Ogbingbin having the poorest rating (5\% good). In Okerewe, the road is rated $60 \%$ good, in Igboya, 55\% good, and in Ilara, $25 \%$ good.

As presented in Table 2, indoor thermal comfort is problematic in the areas considered. In the morning period, it was found that $70 \%$ of residents felt comfortable (comprising the neutral, slightly cool and slightly warm votes) in all the four areas. Also the evening and night are reported to be thermally comfortable indoors by $70-90 \%$ of residents. However, the crucial period for the consideration of thermal comfort in the warm-humid environment is the afternoon period. From Table 2, it can be seen that respondents ratings are $40 \%$ hot and 30\% warm (70\% discomfort) in Okerewe, $45 \%$ hot and $25 \%$ warm (70\% discomfort) in Ogbingbin, $35 \%$ hot and 30\% warm (65\% discomfort) in Ilara and 10\% hot and $10 \%$ warm $(20 \%$ discomfort) in Igboya. This situation is very unacceptable to thermal comfort standards. The results indicate that the design and fabric of the houses are thermally defective. This is further implied by the reported high impact that both sunshine and rainfall have on the indoor conditions in the areas, which are hot discomfort and cold discomfort respectively (Table 3). 
Table 1. Field Survey Results for 4 Central Areas in Ile-Ife- Infrastructure.

\begin{tabular}{|c|c|c|c|c|}
\hline $\begin{array}{l}\text { Infrastucture \& } \\
\text { Amenities }\end{array}$ & $\begin{array}{l}\text { Okerewe - } \\
\text { Itakogun Area }\end{array}$ & Ogbingbin & Ilara - Obalufon & Igboya Area \\
\hline $\begin{array}{l}\text { Sewage } \\
\text { Disposal }\end{array}$ & $\begin{array}{l}20 \% \quad 80 \% \\
\text { Wc Latrine }\end{array}$ & $\begin{array}{lc}20 \% & 80 \% \\
\text { Wc. } & \text { Latrine }\end{array}$ & $\begin{array}{lll}20 \% & 55 \% & 25 \% \\
\text { Wc. } & \text { Latrine } & \text { Free range }\end{array}$ & $\begin{array}{ll}40 \% & 60 \% \\
\text { Wc. } & \text { Latrine }\end{array}$ \\
\hline Telecommunication & $\begin{array}{lc}80 \% & 20 \% \\
\text { Satis } & \text { Disatisfied }\end{array}$ & $\begin{array}{cc}85 \% & 15 \% \\
\text { Satis } & \text { Disatisfied }\end{array}$ & $\begin{array}{lc}45 \% & 55 \% \\
\text { Satis } & \text { Disatisfied }\end{array}$ & $\begin{array}{l}90 \% \\
\text { Satis }\end{array}$ \\
\hline Condition of Road & $\begin{array}{ll}60 \% & 20 \% \quad 20 \% \\
\text { Good } & \text { Fair Bad }\end{array}$ & $\begin{array}{ll}60 \% & 35 \% \\
\text { Bad } & \text { Fair Good }\end{array}$ & $\begin{array}{llll}45 \% & 25 \% & 25 \% & 5 \% \\
\text { Fair } & \text { Bad Good } & \text { V. good }\end{array}$ & $\begin{array}{l}45 \% 35 \% \quad 20 \% \\
\text { Fair Good V.good }\end{array}$ \\
\hline Pipe bome water supply & $\begin{array}{ll}10 \% & 90 \% \\
\text { Erratic } & \mathrm{Bad}\end{array}$ & $\begin{array}{lll}35 \% & 25 \% & 40 \% \\
\text { Erratic } & \text { Bad } & \text { Fair }\end{array}$ & $\begin{array}{ll}75 \% & 25 \% \\
\text { Erratic } & \text { Bad }\end{array}$ & $\begin{array}{ll}70 \% & 30 \% \\
\text { Fair } & \text { Erratic }\end{array}$ \\
\hline Type of water & $\begin{array}{l}100 \% \\
\text { well }\end{array}$ & $\begin{array}{l}100 \% \\
\text { well }\end{array}$ & $\begin{array}{lll}70 \% & 15 \% & 15 \% \\
\text { well } & \text { pipe borne borehole }\end{array}$ & $\begin{array}{ll}80 \% & 20 \% \\
\text { well } & \text { pipe bome }\end{array}$ \\
\hline $\begin{array}{l}\text { Electricity lines/ } \\
\text { Generator power }\end{array}$ & $\begin{array}{l}100 \% \text { connection } / \\
40 \% \text { generators }\end{array}$ & $\begin{array}{l}80 \% \text { connection } / \\
50 \% \text { generators }\end{array}$ & $\begin{array}{l}85 \% \text { connection } / \\
60 \% \text { generators }\end{array}$ & $\begin{array}{l}100 \% \text { connection } / \\
50 \% \text { generators }\end{array}$ \\
\hline Supply of electricity & $\begin{array}{l}60 \% \quad 40 \% \\
\text { Erratic Good }\end{array}$ & $\begin{array}{l}45 \% \quad 25 \% \quad 30 \% \\
\text { Erratic Bad Good }\end{array}$ & $\begin{array}{lll}50 \% & 25 \% & 25 \% \\
\text { Erratic } & \text { Bad } & \text { Good }\end{array}$ & $\begin{array}{ll}85 \% & 15 \% \\
\text { Good } & \text { Erratic }\end{array}$ \\
\hline Refuse Disposal & $\begin{array}{lrr}40 \% & 40 \% & 20 \% \\
\text { Dust } & \text { Gutter Free } \\
\text { Bin } & \text { range }\end{array}$ & $\begin{array}{lccc}65 \% & 15 \% & 10 \% & 10 \% \\
\text { Dust } & \text { Gutter } & \text { Public } & \text { Free } \\
\text { Bin } & & \text { collection } & \text { range } \\
& & & \end{array}$ & $\begin{array}{lcc}50 \% & 45 \% & 5 \% \\
\text { Gutter } & \text { Dustbin } & \text { Public } \\
& & \text { collection }\end{array}$ & $\begin{array}{ll}80 \% & 20 \% \\
\text { Dustbin } & \text { Public } \\
& \text { Collection }\end{array}$ \\
\hline
\end{tabular}

Source: Author's Field Work.

Table 2. Field Survey Results for 4 Central Areas in Ile-Ife- Thermal Comfort.

\begin{tabular}{|c|c|c|c|c|}
\hline Thermal Comfort & Okerewe - Itakogun & Ogbingbin & Ilara - Obalufon & Igboya Area \\
\hline $\begin{array}{l}\text { Thermal feeling - } \\
\text { Moming }\end{array}$ & $\begin{array}{llll}40 \% & 30 \% & 20 \% & 10 \% \\
& & & \\
& & & \\
& \text { cool } & \text { warm }\end{array}$ & $\begin{array}{llc}55 \% & 35 \% & 10 \% \\
\text { cool } & \text { cold slightly cool }\end{array}$ & 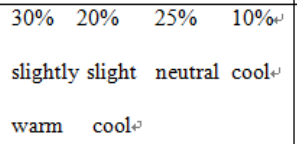 & $\begin{array}{llll}65 \% & 20 \% & 10 \% & 5 \% \\
\text { slightly } & \text { cool } & \text { warm slightly } \\
\text { warm } & & & \text { cool }\end{array}$ \\
\hline $\begin{array}{l}\text { Thermal feeling - } \\
\text { Aftemoon }\end{array}$ & $\begin{array}{l}40 \% \quad 35 \% \quad 20 \% \quad 5 \% \\
\text { hot slightly slightly neutral } \\
\text { warm cool }\end{array}$ & $\begin{array}{c}45 \% 25 \% 25 \% \quad 5 \% \\
\text { hot warm slightly slightly } \\
\text { warm cool }\end{array}$ & $\begin{array}{l}35 \% \quad 30 \% \quad 35 \% \\
\text { hot } \quad \text { warm slightly warm }\end{array}$ & $\begin{array}{llll}50 \% \quad 20 \% & 10 \% & 10 \% \\
\text { slightly slightly hot } & \text { cool } \\
\text { cool warm }\end{array}$ \\
\hline $\begin{array}{l}\text { Thermal feeling - } \\
\text { Evening }\end{array}$ & $\begin{array}{l}40 \% \quad 25 \% \quad 25 \% \quad 10 \% \\
\text { slightly neutral slightly cool } \\
\text { cool } \\
\text { warm }\end{array}$ & $\begin{array}{lcc}60 \% & 30 \% & 10 \% \\
\text { slightly } & \text { warm } & \text { slightly } \\
\text { warm } & & \text { cool }\end{array}$ & $\begin{array}{ccc}30 \% \quad 20 \% & 20 \% & 10 \% \\
\text { neutral cool } & \text { slightly cold } \\
& \\
& \text { cool }\end{array}$ & $\begin{array}{l}50 \% \quad 40 \% \quad 5 \% \quad 5 \% \\
\text { slightly slightly neutral cool } \\
\text { cool warm }\end{array}$ \\
\hline Thermal feeling -Night & \begin{tabular}{llll}
$35 \%$ & $30 \%$ & $20 \%$ & $15 \%$ \\
slightly & cool slightly & neutral \\
cool & \multicolumn{3}{c}{ warm }
\end{tabular} & $\begin{array}{l}40 \% \quad 30 \% \quad 20 \% \quad 10 \% \\
\text { slightly cold cool neutral } \\
\text { cool }\end{array}$ & $\begin{array}{cccc}35 \% & 25 \% & 20 \% & 20 \% \\
\text { cool } & \text { neutral cool } & \text { slightly } \\
& & & \\
& & & \text { cool }\end{array}$ & $\begin{array}{l}30 \% \quad 30 \% \quad 25 \% \quad 5 \% \\
\text { slightly cool neutral cold } \\
\text { cool }\end{array}$ \\
\hline
\end{tabular}

Source: Author's Field Work.

The air quality is perceived to be poor by the residents of the four areas as presented in Table 3. Between 40 and $45 \%$ of the residents perceive odours in the areas. The air movement is relatively low in Okerewe and Ilara with only $10 \%$ and $15 \%$ of residents feeling the effect respectively. The situation is better in Igboya and Ogbingbin with $60 \%$ and $50 \%$ of residents 
feeling the effect respectively. Generally it is found that there is need for improvement in the landscape of all the four areas. The overall assessment given by residents on the quality of the physical built environment indicates that the areas scored poorly in terms of residents' satisfaction. The percentages of residents who felt the built environment was satisfactorily good are low: Ogbingbin- 15\%; Okerewe- 20\%; Ilara- 25\%; Igboya- 35\%.

The major problems identified are listed as follows from the analysis presentation: Poor sewage disposal method; inadequate telecommunication coverage; deplorable roads; very inadequate water and electricity supply with sizeable number of houses not supplied at all. Other identified problems are dirtiness of built environment; poor refuse disposal system; blocked drainages; lack of green areas; congestion of buildings; inadequate ventilation within buildings; low levels of thermal comfort within buildings and poor air quality. Taking the response of the residents, the majority are dissatisfied with the environmental conditions of the Ile-Ife central areas considered in the survey. It is quite evident from this survey that almost all the afore-mentioned problems which are typical of urban central slums are manifested in all the four areas surveyed.

Table 3. Field Survey Results for 4 Central Areas in Ile-Ife- Climatic Impact.

\begin{tabular}{|c|c|c|c|c|}
\hline $\begin{array}{l}\text { Climatic Impact \& } \\
\text { Environment }\end{array}$ & Okerewe - Itakogun & Ogbingbin & Ilara - Obalufon & Igboya Area \\
\hline Feeling inside after rainfall & $\begin{array}{l}65 \% \quad 30 \% \quad 5 \% \\
\text { cold cool neutral }\end{array}$ & $\begin{array}{lll}70 \% & 15 \% & 15 \% \\
\text { cool } & \text { cold } & \text { neutral }\end{array}$ & $\begin{array}{ccc}40 \% & 30 \% & 30 \% \\
& & \\
\text { cool } & \text { cold } & \text { neutral }\end{array}$ & $\begin{array}{ccc}65 \% & 25 \% & 10 \% \\
\text { cool } & \text { cold } & \text { neutral }\end{array}$ \\
\hline $\begin{array}{l}\text { Odour perception during } \\
\text { rainfall }\end{array}$ & $\begin{array}{ll}45 \% & 55 \% \\
\text { odour } & \text { none }\end{array}$ & $\begin{array}{ll}40 \% & 60 \% \\
\text { odour none }\end{array}$ & $\begin{array}{ll}45 \% & 55 \% \\
\text { odour none }\end{array}$ & $\begin{array}{l}40 \% \quad 60 \% \\
\text { odour none }\end{array}$ \\
\hline $\begin{array}{l}\text { Feeling inside during } \\
\text { sunshine }\end{array}$ & $\begin{array}{lll}60 \% & 30 \% & 10 \% \\
\text { hot } \quad \text { warm } & \text { slightly } \\
& & \text { warm }\end{array}$ & \begin{tabular}{llll}
$55 \%$ & $40 \%$ & $10 \%$ & $5 \%$ \\
hot & warm & slightly cool \\
& \multicolumn{3}{c}{ warm }
\end{tabular} & $\begin{array}{l}40 \% \quad 30 \% 25 \% 5 \% \\
\text { slightly warm hot cool } \\
\text { warm }\end{array}$ & $\begin{array}{c}55 \% \quad 30 \% \quad 10 \% \quad 5 \% \\
\text { warm slightly hot cool } \\
\text { warm }\end{array}$ \\
\hline Air movement & $\begin{array}{l}10 \% \quad 90 \% \\
\text { felt not felt }\end{array}$ & $\begin{array}{ll}50 \% & 50 \% \\
\text { felt } & \text { not felt }\end{array}$ & $\begin{array}{ll}15 \% & 85 \% \\
\text { felt } & \text { not felt }\end{array}$ & $\begin{array}{l}60 \% \quad 40 \% \\
\text { felt not felt }\end{array}$ \\
\hline $\begin{array}{l}\text { Improvement in landscape } \\
\text { needed }\end{array}$ & $\begin{array}{l}60 \% \\
\text { needed }\end{array}$ & $\begin{array}{l}60 \% \\
\text { needed }\end{array}$ & $\begin{array}{l}75 \% \\
\text { needed }\end{array}$ & $\begin{array}{l}60 \% \\
\text { needed }\end{array}$ \\
\hline Comment on environment & $\begin{array}{ll}20 \% \quad 60 \% & 20 \% \\
\text { Good Fair } & \text { Bad }\end{array}$ & $\begin{array}{lll}15 \% & 50 \% & 35 \% \\
\text { Good } & \text { Fair } & \text { Bad }\end{array}$ & $\begin{array}{llll}10 \% & 15 \% & 30 \% & 45 \% \\
\text { V.good Good Fair } & \text { Bad }\end{array}$ & $\begin{array}{llll}20 \% & 15 \% & 35 \% & 30 \% \\
\text { V.good Good Fair } & \text { Bad }\end{array}$ \\
\hline
\end{tabular}

Source: Author's Field Work.

From the analysis of the infrastructure in the areas, one of the major problems identified is in relation to the distribution and use of energy. There is inadequate and irregular supply of electricity in the city central areas. This resulted in the use of generating sets by residents. This has added to the level of environmental pollution and in the long run would affect the national fossil fuel reserves. Indoor discomfort is experienced in most of the houses. The air movement is minimal because of the high building density in the core areas. The high discomfort experienced inferred that the houses were actually not well designed to cater for the challenges of the warm-humid climate. The level of sanitation is poor. Portable water 
supply is not guaranteed and sewage and refuse disposal are defective. These conditions of the environment constitute a health hazard for both the residents and passersby alike. The Ile-Ife core areas, like most other core areas in other cities in Nigeria need urgent attention because of all the environmental problems identified through the survey.

\section{Discussion on the Applicable Sustainable Urban Renewal Strategy}

After identifying the deplorable extent of the housing and environmental problems in the study area, it is pertinent to examine and recommend viable urban renewal solutions for Nigerian cities. Urban renewal is the redevelopment of urban areas that have become run down or impoverished, by demolishing or renovating old buildings or building new ones. This is more or less an aspect of city planning which is the planning of the physical and social development of a city through the design of its layout and the provision of services and facilities (Encarta Encyclopedia 2008). Urban renewal is presented as a necessary emergency intervention for the transformation of the cities in Nigeria and the developing world. The solution can only be effectively embarked on as an urban governance instrument of action. The recommended concept demands that urban designers and planners need to take environmental and neighborhood concerns into account before proceeding with the programmes. The local situation in each city and city neighbourhood need to be assessed and taken into consideration along with the socio-economic and cultural realities. While learning from the programmes conducted elsewhere, it must be clarified that the successful solutions to housing and environmental problems cannot be generalised in application and would need peculiar modifications for effectiveness.

In order to fortify this solution in Nigerian situation therefore, it is germane to make suggestions toward the development of a comprehensive conceptual framework for a government-instituted policy of urban renewal. The realization that governance at all the three levels- federal, state and local governments need to address the issue of urban renewal in the cities of Nigeria will go a long way in making the transformation of the country possible. According to Ooi and Phua (2007), strategic planning and intervention by government are major issues towards managing rapid urbanization. This paper is advocating a broad-based intervention to tackle the identified problems of urban housing and environment and improve the quality of life of city residents. A comprehensive multi-faceted approach for the urban renewal programme is hereby presented in this section.

The environmental need in a developing country like Nigeria is the improvement of urban living standards at minimal costs without destroying the natural environment as entrenched in the principle of sustainable development (Edwards 1999). The present trend of urban growth and development as found in the study area is totally unsustainable. Sustainable development has been described as meeting the needs of the present generation without compromising the ability of future generations to meet their own needs. Additional work in the field of sustainable development that relate to this research has been done. They include the following (Costanza et al 1992, Amekudzi et al 2009, Huzayyin and Salem 2013, Paz et al 2013, Maheshwari et al 2014) that specifically talk about the state of the art practices and methodologies that affect urban housing and environment due to its interdependencies with 
transportation, and the economic and social sectors. For sustainable urban growth and development, the entire urban housing stock has to be well integrated in a comprehensive urban sustainability programme. The improvement of urban living standards at minimal costs is the urgent need in developing countries. This improvement must be in harmony with the natural environment.

A key issue in the sustainability of the urban environment is the energy use in the cities which was confirmed as a problem in the study area. In accord with the basic arguments of sustainability, it is important to note that urban growth and development can be partly sustainable if the energy use within urban buildings is drastically reduced or moderated and made to be efficient. The expenditure of both material and financial resources on energy in the urban built environment needs to be addressed. As part of the requirement for sustainable environment also, there is the need for the occupants of residential buildings not to be over-burdened by the running and maintenance costs of their apartments and their environment. There is a need for significant improvement in the rate of energy consumption of several buildings in use. The target is actually to reduce the rate at which fossil fuels are being expended as well as limit the production of carbon-dioxide and other harmful gases through their combustion. Holmes and Hacker (2006) as well as Bragança and Pinheiro (2007) advocated the use of low-energy strategies for attainment of energy efficiency and sustainability in buildings.

In addressing this energy issue, the factors to be evaluated are listed as four by Baker and Steemers (2000). They are: 1.The building design 2.Services design and performance 3.Occupant behaviour 4.Presence of high energy activity/process within the building. The principal concepts that have been used to tackle the excessive use of energy through these listed factors are energy efficiency, energy conservation and renewable energy. According to Baker and Steemers (2000), there is need to design low energy buildings without reducing the internal environmental quality. Hyde (2000) recommended passive building design to avoid dependence on active energy mechanism for indoor comfort and illumination. Energy efficiency has proved to be a cost-effective strategy for building economies without necessarily growing consumption.

Sustainability of the built environment can be enhanced through the attainment of indoor thermal comfort at little or no cost to the building user. This however is a challenge in urban buildings within tropical climates because of the influence of climatic elements and the pollutions generated in the urban environment (Hyde 2000, Cheng et al 2011). Attainment of thermal comfort within residential living spaces also induces user satisfaction. The architecture of residential buildings should collaborate with nature to establish an order in which human beings may live in harmony with their surroundings. Croome (1991) asserted that buildings modify climate and influence behaviour and culture. A major aspect of the environmental quality is the thermal comfort within the building spaces. Both building and urban design need the input of the research findings on thermal comfort because building thermal comfort affects sustainability of the urban environment. It is hereby submitted therefore that the master plan of new urban centres should be prepared with adequate thermal comfort considerations at both the micro and macro levels. 
Comprehensive re-planning is needed in urban central areas to attain and sustain a satisfactory state of health, order, convenience, progress and general well-being of the community. From earliest times, man has striven to attain a perfect physical environment (Ratcliffe, 1981). Successful urban planning should involve ordering the use of land and siting of buildings and communication routes so as to secure the maximum practicable degree of economy, convenience and beauty (Keeble 1969, McLaughlin 1969). The zoning of different human activity areas should therefore be effected in the re-design of the cities. The urban centre can be renewed by general city planning and re-planning of the physical and social development through the appropriate design of its layout and the provision of all services and facilities. The provision of effective services and infrastructure like pipe-borne water and electricity will go a long way in making the urban environment sustainable. There is a need to examine developmental concepts for environmental quality to improve the city environment and eliminate the global problems caused by the pollutions in the urban centres. To this end, appropriate and reliable sewage and waste disposal systems need to be provided for each house and neighbourhood.

Appropriate building densities have to be considered for neighbourhoods in city master plans and urban renewal projects. A decongestion programme should be embarked on for presently high density neighbourhoods to reduce overcrowding and the attendant problems. There should be introduction of green areas with the demolition of some structures which should be relocated into less densely populated areas. Trees should be planted in all neighbourhoods in the city to enhance air movement and provide shade from the heat of direct solar radiation. The lawful setbacks for buildings from roads and other buildings in urban areas should be enforced and narrow roads should be widened to the required standards. This will allow for more air movement within the urban areas and reduce traffic congestion. Recreational parks should be introduced in city central areas to help in reducing air temperatures within the high density city central areas.

A renovation of buildings should be done to include the provision of effective sun-shading devices for all exposed windows to reduce heat gains. Patios, pagolas and overhangs should also be appropriately utilized where possible to reduce insolation. The painting for dark coloured external walls should be changed to bright colours to improve the indoor thermal conditions since the bright colours would absorb less solar heat. Energy-efficient electric lighting fittings should be utilized in residential buildings. Incandescent bulbs should be phased out because they are not energy-efficient and produce significant amount of heat which adds up to the discomfort indoors.

For the urban renewal programme to work and to be effective and sustainable, the owners of the concerned residential buildings should be asked to pay for whatever work of renovation or reconstruction is done on their respective buildings. It is proposed that convenient payment schedules should be worked out for each house owner. The renewal programme should be contracted out to professionals by the government on behalf of the people with the people duly represented at every level of the process to ensure participatory democracy in governance as advocated by Mabogunje (2011). The projects should be financed by Mortgage Institutions and heavily subsidized by the Federal Government and the respective State 


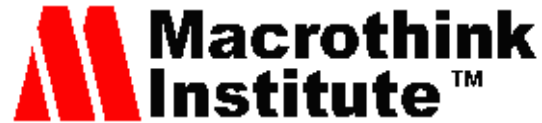

Governments. New buildings in new neighbourhoods should also be constructed as part of the government-intervention programme for the purpose of housing the homeless in the cities. For the new construction, both government and private developers should be involved and the emphasis should be on low-cost housing. Though the solutions to all the urban housing and environmental problems are not easily realizable, there must be a commitment on the part of the people in authority at the different levels of governance to executing the urban renewal programme. The cooperation and support of the urban populace will also be indispensable as well as the input from relevant professionals and researchers.

\section{Conclusion}

It must be emphasized that uncontrolled urbanization has contributed immensely to the problems of central areas of cities in developing countries with challenges in key aspects like urban housing quality and quantity, socio-economic and infrastructural development, environmental quality as well as energy demand. Although the housing and environmental assessment and appraisal conducted in this study was limited in scope to neighbourhoods in one typical city in Nigeria, Ile-Ife, the results give insight that housing challenges of the urban central areas are generally in unsustainable dimensions and are predicated on the stress of uncontrolled urbanization. With the discussion on the applicable sustainable urban renewal strategy for Nigerian cities, this paper hinged on the dimension of government-instituted urban renewal policy providing a means of mitigating the housing sustainability challenges with respect to the Nigerian urban context. Government intervention in the dynamics of the urban environment in Nigeria is highly required to reverse the depreciating urban conditions. There must be a commitment on the part of the people in authority to execute comprehensive urban renewal programmes and general city re-design with a focus on sustainability. To have impactful governance, effective urban management needs to be addressed by improving the urban living conditions.

\section{Acknowledgement}

The author acknowledges the support of the Global Excellence Stature (GES) Postdoctoral Fellowship of the University of Johannesburg.

\section{References}

Amekudzi, A. A., Khisty, C. J., \& Khayesi, M. (2009). Using the sustainability footprint model to assess development impacts of transportation systems. Transportation Research Part A, 43, 339-348.

Baker N., \& Steemers K., (2000). Energy and Environment in Architecture. A Technical Design Guide. London: E \& FN Spon.

Bragança, L., \& Pinheiro, M. (2007). Portugal SB07 Sustainable Construction,Materials and Practices- Challenge of the Industry for the New Millennium. Portugal: IOS Press.

Cheng, V., Ng, E., Chan, C., \& Givoni B., (2011). Outdoor thermal comfort study in a sub-tropical 
climate: a longitudinal study based in Hong Kong. Int. Journal of Biometeorology. Available from

http://www.ncbi.nlm.nih.gov/pubmed/21197549. [Accessed 10 Aug.2011].

Costanza, R., Norton, B., \& Haskell, B. D. (1992). Ecosystem Health: New Goals for Environmental Management, Island Press Washington, D.C., U.SA.

Croome D. J. (1991). The Determinants of architectural form in modern buildings within the Arab world. Building and Environment, 26(4), 349-362.

Edwards B., (1999). Sustainable Architecture, European directives and Building Design. Oxford: Architectural Press.

Encarta Encyclopedia., (2008). 'Urban Renewal'; 'Cities with urban renewal projects'; 'City planning; 'Housing and Urban development'. Encarta Premium 2008. Microsoft Corporation.

Holmes M., \& Hacker J. N., (2006). Low Energy Design Techniques for a sustainable future. Paper presented at Conference on Comfort and Energy use in Buildings-Getting it right. Cumberland, Windsor park UK April 2006. Windsor: NCEUB.

Huzayyin, S., \& Salem, H. (2013). Analysis of thirty years evolution of urban growth, transport demand and supply, energy consumption, greenhouse and pollutants emissions in Greater Cairo. Research in Transportation Economics, 40(1), 104-115.

Hyde R., (2000). Climate Responsive Design. London: E \& FN Spon.

Keeble L., (1969). Principles and Practice of Town and Country Planning. Great Britain: Estate Gazette.

Mabogunje A., (1978). Towards an urban Policy in Nigeria. In: Sada P.O and J.S Oguntoyinbo (eds), Urbanization Processes and Problems in Nigeria. Ibadan: Univ Press, 7-20.

Mabogunje A., (2002). Re-constructing the Nigerian city: The New Policy on urban development and housing in Amole B et al (eds), The City in Nigeria. Ile-Ife: OAU Press.

Mabogunje A., (2011). Urban Governance and Resource Management: Revisiting the 1976 Local Government Reform in Nigeria. In Adeyemo R. (ed), Urban Agriculture, Cities and Climate Change. Germany: Göttingen.Cuvillier Verlag, 1-11.

Maheshwari, P., Khaddar, R., Kachroo, P., \& Paz, A. (2014). Dynamic Modeling of Performance Indices for the Planning of Sustainable Transportation Systems. Networks and Spatial Economics, DOI: 10.1007/s11067-014-9238-6.

McLoughlin J. B., (1969). Urban and Regional Planning. A systems approach. Great Britain: Faber.

Ogunshakin L. (1994). Urban Housing Policies in the Third World. Ekistics, 336, 367, 170-174. 


\section{Macrothink}

Environmental Management and Sustainable Development

ISSN 2164-7682 2015, Vol. 4, No. 2

Ojo G. J. A., (1978). Action-oriented observations for urban development. In Sada P.O. and J.S.

Oguntoyinbo (eds), Urbanization Processes and Problems in Nigeria. Ibadan: University Press, 21-30

Okoko E., (2001). Residential crowding and privacy in high-density neighbourhoods in Akure, Nigeria. Ife Social Sciences Review, 19(1), 133-144.

Olotuah A. O., (2005). Urbanization, Urban Poverty and Housing Inadequacy in Akure metropolis. In Proceedings of Africa Union of Architects Congress, 23-28 May, Abuja , Nigeria. pp 185-199.

Ooi G. L., \& Phua K. H. (2007). Urbanization and Slum formation. J. Urban Health, 84(1), 27-34.

Paz, A., Maheshwari, P., Kachroo, P., \& Ahmad, S. (2013). Estimation of Performance Indices for the Planning of Sustainable Transportation Systems. Advances in Fuzzy Systems. http://dx.doi.org/10.1155/2013/601468.

Ratcliffe J. (1981). An introduction to Town and Country Planning. London: Hutchinson \& Co.

United Nations Development Programme., 2001. The Millennium Development Goals. Available from: www.undp.org/mdg; www.unmilleniumproject.org/html [Accessed 20 Aug. 2010].

United Nations Development Programme, (2005). UN Millenium Project- Investing in Development: A Practical Plan to achieve the Millenium Development Goals. U.K: Earthscan.

\section{Copyright Disclaimer}

Copyright for this article is retained by the author(s), with first publication rights granted to the journal.

This is an open-access article distributed under the terms and conditions of the Creative Commons Attribution license (http://creativecommons.org/licenses/by/3.0/). 